\title{
IBU-IBU ONLINE : ANTARA KUIS HUNTERS (KUTERS) DAN PELAKSANA FUNGSI DALAM KELUARGA
}

\author{
Mira Hasti Hasmira
}

\section{Universitas Negeri Padang}

\begin{abstract}
Abstrak
Artikel ini mendeskripsikan keberfungsian keluarga pada lima keluarga ibuibu yang kecanduan internet, yang tergabung dalam kuters (kuis hunters) di Indonesia. Dalam artikel ini dijelaskan bahwa ibu-ibu kuters tergolong pengguna internet secara sehat karena masih melakukan komunikasi dan interaksi dengan orang-orang disekitar dengan baik dan memiliki komunitas "kopdar" dengan sesama kuters. Sedangkan terhadap anak-anak secara tidak sadar ibu telah memberikan sosialisasi sebagai pecandu internet dengan melibatkan anak dan suami dalam mengikuti berbagai kuis online, sehingga anak juga mengikuti kebiasaan perilaku ibu. Beberapa proses yang sangat mempengaruhi hasil interaksi antara anak-anak dengan ibu pecandu internet, yaitu: imitasi perilaku online, sugesti yang diberikan ibu, dalam proses identifikasi, dan simpati yang diwujudkan melalui sebuah kerjasama.
\end{abstract}

Kata Kunci : fungsi sosialisasi; kecanduan internet

\section{Abstract}

This article describes the function of a family within five mothers who are addicted to the Internet. Spesifically, they addicted with the quiz that is called 'kuters' (quiz hunters) in Indonesia. The article explains that mothers kuters are categorized as relatively healthy internet users. This is because they are still doing good communication and interaction with people around. Additionally, they follow their communication by gathering with fellow kuters in reality sometimes. Unfortunately, the children of five mothers unconsciously also involved with mothers' internet activities. They have been socialized by involving their children and husband to participate in various quizzes online that cause children also follow the behavioral habits of the mother. The interaction processes of mother who are addicted internet with their children affected the children such as imitation online behavior, mother's suggestion, identification process and feeling sympathy through a cooperation with mothers.

Keywords : Social functions; internet addiction

\section{Pendahuluan}

Keluarga sebagai unit terkecil dalam masyarakat mempunyai pengaruh yang besar bagi bangsa dan negara. Dari keluargalah akan terlahir generasi penerus yang akan menentukan nasib bangsa. Apabila keluarga dapat menjalankan fungsi dengan baik, maka sangat dimungkinkan tumbuh generasi yang

Jurnal Socius Vol. 3, No.1, Th. 2016 berkualitas dan dapat diandalkan. Sebaliknya bila keluarga tidak dapat berfungsi dengan baik, bukan tidak mungkin akan menghasilkan generasigenerasi yang bermasalah yang dapat menjadi beban sosial masyarakat. Keberfungsian keluarga sangat ditentukan oleh proses-proses yang berlangsung di dalamnya. 
Ibu merupakan sosok sentral dalam sebuah keluarga. Terlaksananya fungsifungsi dalam keluarga terutama fungsi sosialisasi sangat dipengaruhi dengan keberadaan seorang ibu. Fenomena yang sangat menarik adalah adanya ibu-ibu ini terlibat aktif dalam sebuah kelompok yang mereka namai Kuters (Kuis Hunters). Kuters adalah sebutan untuk para pemburu hadiah melalui kuis-kuis yang ada di internet. Media jejaring sosial seperti facebook adalah wadah utama adanya berbagai kuis dengan beragam hadiah menarik, mulai dari pulsa, produk, uang cash bahkan tiket umroh sekeluarga dan paket liburan keluar negeri. ${ }^{1}$

Para pelaku kuis Hunters ini mengikuti berbagai kuis online yang ada di facebook, twitter atau blog atau website resmi milik penyelenggara kuis. Bentuk kuis yang ada misalnya lomba foto, narasi berkaitan produk sponsor panitia atau berkaitan dengan tema-tema tertentu. Menariknya para Kuters yang online hampir 12 jam sehari ini mendapatkan dukungan dari keluarga baik suami maupun anak-anaknya. Dilihat dari durasi yang dihabiskan ibu-ibu kuters ini dalam ber-internet, mereka dipastikan sebagai ibu-ibu yang kecanduan internet.

Berbeda dengan tulisan-tulisan yang telah ada sebelumnya, kecanduan internet lebih sering dilihat pada anak-anak, remaja dan mahasiswa. Dari penelusuran yang telah dilakukan, belum ditemukan tulisan tentang ibu-ibu yang kecanduan internet. Terkait dengan perannya sebagai seorang ibu, tentu saja mempengaruhi bagaimana ibu dalam melaksanakan fungsi-fungsi dalam keluarga terutama fungsi sosialisasi.

\footnotetext{
${ }^{1}$ Wawancara dengan beberapa Ibu Kuters, Mei 2014
}

Jurnal Socius Vol. 3, No.1, Th. 2016 ISSN: 2356-4180
Menurut Koerner dan Fizpatrick $(2004)^{2}$, defenisi tentang keluarga setidaknya dapat ditinjau berdasarkan tiga sudut pandang, yakni : Defenisi struktural, keluarga didefenisikan berdasarkan kehadiran atau ketidakhadiran anggota keluarga, seperti orang tua, anak dan kerabat lainnya. Defenisi ini memfokuskan pada siapa yang menjadi bagian dari keluarga. Dari perspektif ini dapat muncul pengertian tentang keluarga sebagai asal usul (families of origin), keluarga sebagai wahana melahirkan keturunan (families of pro creation) dan keluarga batih (nuclear family). Defenisi fungsional, keluarga didefenisikan dengan penekanan pada terpenuhinya tugas-tugas dan fungsi-fungsi psikososial. Fungsifungsi tersebut mencakup perawatan, sosialisasi pada anak, dukungan emosi dan materi, dan pemenuhan peran-peran tertentu. Defenisi ini memfokuskan pada tugas-tugas yang dilakukan oleh keluarga. Defenisi transaksional, keluarga didefenisikan sebagai kelompok yang mengembangkan keintiman melalui perilaku-perilaku yang rasa identitas sebagai keluarga (family identity), berupa ikatan emosi, pengalaman historis, maupun cita-cita masa depan. Defenisi ini memfokuskan pada bagaimana keluarga melaksanakan fungsinya.

Keluarga ibu-ibu kuters yang dideskripsikan dalam artikel ini lebih kepada keluarga dilihat dari defenisi transaksional yang memfokuskan kepada bagaimana ibu sebagai anggota keluarga aktif menggunakan internet dalam melaksanakan fungsinya.

Menurut Berns (2004), keluarga memiliki lima fungsi dasar, yaitu ${ }^{3}$ :

\footnotetext{
${ }^{2}$ Sri Lestari. 2012. Psikologi Keluarga. Jakarta: Kencana Prenada Media Grup, hal: 4-5

${ }^{3}$ Ibid. hal: 22
} 
Reproduksi, keluarga memiliki tugas untuk mempertahankan populasi yang ada dalam masyarakat. Sosialisasi/edukasi, keluarga menjadi sarana untuk transmisi nilai, keyakinan, sikap, pengetahuan, keterampilan, dan teknik dari generasi sebelumnya ke generasi yang lebih muda. Penugasan peran sosial, keluarga memberikan identitas pada para anggotanya, seperti ras, etnik, religi, sosial, ekonomi dan peran gender. Dukungan ekonomi, keluarga menyediakan tempat berlindung, makanan dan jaminan kehidupan. Dukungan emosi/ pemeliharaan, keluarga memberikan pengalaman interaksi sosial yang pertama bagi anak. Interaksi yang terjadi bersifat mendalam, mengasuh dan berdaya tahan sehingga memberikan rasa aman pada anak.

Dalam artikel ini, lebih memfokuskan untuk melihat bagaimana ibu-ibu kuters melaksanakan fungsi sosialisasi. Terkait dengan keluarga, sosialisasi dapat didefenisikan sebagai proses yang diinisiasi oleh orang dewasa untuk mengembangkan anak melalui insight, pelatihan dan imitasi, guna mempelajari kebiasaan dan nilai-nilai yang kongruen dalam beradaptasi dengan budaya. Melalui sosialisasi diharapkan anak memiliki kebiasaan yang adaptif dan nilai-nilai yang relevan dengan budaya setempat. ${ }^{4}$

Fungsi sosialisasi menunjuk pada peranan keluarga dalam membentuk kepribadian anak. Melalui fungsi ini, keluarga berusaha mempersiapkan bekal selengkap-lengkapnya kepada anak dengan memperkenalkan pola tingkah laku, sikap, keyakinan, cita-cita dan nilainilai yang dianut oleh masyarakat serta mempelajari peranan yang diharapkan

${ }^{4}$ Ibid hal 87

Jurnal Socius Vol. 3, No.1, Th. 2016 ISSN: 2356-4180 akan dijalankan mereka. Dengan demikian, sosialisasi berarti melakukan proses pembelajaran terhadap seorang anak. Belajar tidak selalu diartikan sebagai suatu aktifitas yang sifatnya semata-mata intelektual, tetapi mencakup hal lain yaitu pengamatan. Melalui proses belajar mengajar dalam keluarga ini, anak mengetahui bagaimana cara berpikir dari kelompoknya itu. ${ }^{5}$

Proses sosialisasi tidak sewajarnya diberikan kepada orang lain. Peran orang tua sangat besar dalam proses sosialisasi ini sebab dari anak akan meniru segala yang dilihat dan dipelajari dari orang tuanya. Apabila orang tua tidak menjalankan fungsi sosialisasi dengan baik, problem yang muncul adalah anak kehilangan perhatian. Setelah itu dia mencari tokoh lain selain orang tuanya untuk ditiru.

Keluarga merupakan sumber utama dalam prose penanaman nilai dan norma. Penanaman ini dilakukan melalui interaksi sosial. Dalam interaksi ini, kemudian terjadi proses internalisasi. Ada beberapa faktor yang memberikan pengaruh terhadap seseorang dari hasil interaksi sosial, sebagai berikut ${ }^{6}$ : Imitasi (meniru). Kecenderungan meniru merupakan naluri yang mempunyai peranan yang sangat penting dalam proses interaksi sosial. Dampak positif dari imitasi adalah mendorong seseorang untuk mematuhi norma dan nilai yang berlaku. Seorang ayah yang memberikan contoh bagaimana cara makan yang baik dalam keluarga, akan ditiru oleh anggota keluarga lainnya. Imitasi juga biasanya dilakukan oleh seorang anak terhadap anggota keluarga yang jenis kelaminnya sama. Anak

\footnotetext{
5 Hendi Suhendi, dan Ramdani Wahyu. 2001. Pengantar Studi Sosiologi Keluarga. Bandung: Pustaka Setia Bandung, hal : 45-46

${ }^{6}$ Ibid hal: 108-109
} 
kemudian mengidentifikasikan dirinya dengan orang tuanya yang berjenis kelamin sama dengan dirinya. Sugesti. Faktor sugesti berlangsung bila seseorang memberi pandangan atau sikap yang berasal dari dirinya kemudian sikap itu diterima pihak lain. Umumnya, sugesti yang merupakan anjuran dapat melahirkan reaksi langsung tanpa memerlukan pemikiran secara rasional, tetapi diterima secara emosional. Misalnya, orang tua yang menceritakan keberhasilannya dalam studi dengan menggunakan metode belajar tertentu akan memberikan motivasi langsung kepada anaknya. Identifikasi. Identifikasi merupakan kecenderungan atau keinginan dalam diri seseorang untuk menjadi sama dengan pihak lain. Proses ini dapat berlangsung secara tidak wajar maupun dengan sengaja. Dalam hal ini seseorang merasa ingin dirinya menjadi tokoh idolanya yang dihormati dan dikagumi karena kedudukannya yang lebih tinggi atau mungkin tipe-tipe ideal itu mempunyai kelebihan tertentu yang dapat dijadikan panutan dan teladan untuk dirinya. Identifikasi ini ditekankan pada upaya mengidentikkan seseorang. Simpati. Simpati ialah kesenangan seseorang untuk langsung merasakan sesuatu dengan orang lain. Perasaan simpati banyak timbul dari hubungan antar manusia dan manusia lainnya. Wujud simpati adalah melakukan kerjasama atau tolong menolong.

Setelah seseorang mengetahui tata nilai disekelilingnya, dia akan berfikir dan mengetahui nilai-nilai yang perlu ia kerjakan. Dalam proses berfikir, ia kemudian memahami nilai-nilai itu sehingga tertanam (internalisasi) dalam dirinya. Selanjutnya ia mempraktekkan nilai-nilai tersebut dalam kehidupan sehari-hari. Nilai-nilai yang sudah dipraktekkan itu lama kelamaan berubah menjadi norma-norma.

Jurnal Socius Vol. 3, No.1, Th. 2016 ISSN: 2356-4180
Kuters (kuis Hunters) merupakan istilah yang dibuat oleh para peserta kuis online namun tak diketahui dengan pasti siapa yang pertama kali mencetuskan ide ini. Istilah ini muncul sejak tahun 2011 yang menjadi sebuah komunitas di dunia maya. Komunitas yang di dominasi oleh para ibu rumah tangga ini memiliki ketertarikan yang sama, yaitu sama-sama tertarik sebagai peserta kuis online di berbagai jejaring sosial. Sering mengikuti kuis yang sama dan membutuhkan banyak like seperti di facebook untuk bisa memenangkan berbagai hadiah, membuat kelompok ini menjadi saling membutuhkan dan akhirnya meningkat menjadi perkenalan di dunia maya dan akhirnya juga diikuti dengan beberapa perkenalan di dunia nyata yang mereka namai kopdar (kopi darat), bagi yang bisa. ${ }^{7}$

Kuters bisa dikatakan termasuk dalam virtual communities atau komunitas maya, yaitu komunitas yang lebih banyak muncul di dunia elektronik dibandingkan dengan di dunia nyata. Salah satu bentuknya yang paling awal adalah buletin komputer yang diakses dengan menyambungkan modem pada tahun 1970. Ruang chatting, email, milis dan kelompok-kelompok diskusi via elektronik adalah contoh baru tempattempat yang dapat dipakai oleh komunitas untuk saling berkomunikasi. Orang yang tinggal di berbagai penjuru dunia yang memiliki ketertarikan sama dapat berkumpul untuk membicarakannya dalam dunia maya. ${ }^{8}$

Aktivitas ibu-ibu kuters dijelaskan dalam tulisan ini adalah aktivitas yang terjadi di jejaring sosial facebook.

\footnotetext{
${ }^{7}$ Wawancara dengan beberapa ibu kuters

${ }^{8}$ Warner J Severin. 2011. Teori Komunikasi : Sejarah, Metode dan Terapan di Dalam Media Massa, Jakarta: Kencana Prenada MediaGrup., hal: 447
} 
Facebook adalah sebuah yang diluncurkan pada bulan Februari 2004, dimiliki dan dioperasikan oleh Facebook, Inc. Pada September 2012, Facebook memiliki lebih dari satu miliar pengguna aktif, lebih dari separuhnya menggunakan telepon genggam. Pengguna harus mendaftar sebelum dapat menggunakan situs ini. Setelah itu, pengguna dapat membuat profil pribadi, menambahkan pengguna lain sebagai teman, dan bertukar pesan, termasuk pemberitahuan otomatis ketika mereka memperbarui profilnya.

Facebook didirikan oleh Mark Zuckerberg bersama teman sekamarnya dan sesama mahasiswa Universitas Harvard, Eduardo Saverin, Andrew McCollum, Dustin Moskovitz dan Chris Hughes. Keanggotaan situs web ini awalnya terbatas untuk mahasiswa Harvard saja, kemudian diperluas ke perguruan lain di Boston, Ivy League, dan Universitas Stanford. Situs ini secara perlahan membuka diri kepada mahasiswa di universitas lain sebelum dibuka untuk siswa sekolah menengah atas, dan akhirnya untuk setiap orang yang berusia minimal 13 tahun.

Facebook akhirnya mau membuka kantor di Jakarta karena 65 juta pengguna Facebook berasal dari Indonesia dan 90 persen di antaranya menggunakan jejaring sosial ini dengan aktif. Indonesia juga merupakan negara pengguna Facebook keempat terbesar di dunia. ${ }^{9}$

Facebook masih menjadi media sosial favorit di Indonesia meskipun saat ini kepopulerannya mulai tersaingi oleh platform lain, seperti Path dan aplikasi pesan instan. Menurut Anand Tilak, Head of Facebook Indonesia, jumlah pengguna aktif Facebook di Indonesia tiap bulannya

\footnotetext{
${ }^{9}$ Reza Wahyudi. 2014. Facebook Buka Kantor di Indonesia, Kompas.com .21 Maret 2014.
}

Jurnal Socius Vol. 3, No.1, Th. 2016 mencapai 69 juta orang, 61 juta di antaranya berasal dari gadget mobile. Tingginya penetrasi Facebook juga didukung oleh hasil survei yang dilakukan oleh TNS Insight Report. Menurut lembaga survei tersebut, Facebook masih memiliki penetrasi tertinggi dibanding semua platform jejaring sosial di Indonesia. Jika dibandingkan dengan media sosial lain, Facebook masih memiliki pangsa pasar 98 persen di Indonesia. Google Plus berada di peringkat dua dengan torehan 54 persen. Sementara itu, jejaring sosial 140 karakter, Twitter, berada di peringkat tiga dengan capaian 44 persen. Menyusul di belakangnya adalah Yahoo Messenger (42 persen), WhatsApp (21 persen), WeChat (16 persen), Line (10 persen), Instagram (5 persen), dan Skype (4 persen). ${ }^{10}$

Internet yang sering digeluti dan dipuja sebagai sebuah alat yang mampu menyediakan berbagai informasi dan hiburan serta alat canggih pembantu kesuksesan, ternyata dapat menimbulkan bahaya kecanduan. Kecanduan internet menyerang masuk sekolah-sekolah, kantor-kantor dan bahkan rumah-rumah.

Kecanduan internet dapat didefenisikan sebagai pemakaian internet secara berlebihan yang ditandai dengan gejala-gejala klinis kecanduan, seperti keasyikan dengan objek candu, tidak memperdulikan dampak fisik maupun psikologis pemakaian dan sebagainya (Young, 1996). ${ }^{11}$

Seorang pecandu internet tidak merasa dirinya kecanduan internet bahkan tidak mau disebut pecandu internet karena tidak menyadari bahwa perilaku online

\footnotetext{
10 Reska K. Nistanto.2014.Facebook Ungkap Jumlah Penggunanya di Indonesia. Kompas.com. Senin, 22 September 2014.

${ }^{11}$ Ibid, hal 462
} 
nya berlebihan. Pecandu internet tidak dapat menghentikan keinginannya untuk online sehingga kehilangan kontrol dari penggunaan internet dan kehidupannya. ${ }^{12}$

Penulis mengkategorikan Kuters sebagai sebuah kecanduan internet karena ibu-ibu Kuters bisa online hampir 10-12 jam sehari dan bahkan mengaku pernah sakit kurang istirahat. Hadiah-hadiah yang ditawarkan menjadi candu bagi par ibuibu Kuters.

Suler menyatakan pengguna internet dapat digolongkan menjadi dua golongan ${ }^{13}$, yaitu : Pengguna internet yang menggunakan internet secara sehat, artinya golongan ini mampu memadukan kehidupan nyata dengan dunia cyberspace. Individu-individu tersebut membicarakan aktivitas online dengan keluarga dan teman-teman, menggunakan identitas, minat dan keahlian yang sebenarnya dalam komunitas online, menelpon dan bertemu langsung dengan orang yang dikenal melalui aktivitas online, atau bertemu dengan teman yang dikenal dalam dunia maya melalui internet. Pengguna internet yang menggunakan internet secara tidak sehat. Pada bagian ini individu-individu memisahkan antara kehidupan nyata dengan dunia cyberspace. Aktivitas cyberspace menjadi dunia tersendiri, tidak dibicarakan dengan orang-orang dalam kehidupannya.

12 K.S.Young,1996. Internet Addiction : The Emergence of A New Clinical Disorder. Paper presented at the 104th annual meeting of the American Psychology Association, Canada, August 15.

${ }^{13}$ J. Suler. 1996. Computer and Cyberspace Addiction (online). Rider University : http://www1.Rider.edu/-

suler/psycyber/psycyber.html

Jurnal Socius Vol. 3, No.1, Th. 2016

ISSN: 2356-4180
Young 14 juga membedakan pengguna internet sebagai berikut : Pengguna internet yang menggunakan internet secara normal, disebut dengan non dependent. Pengguna pada kelompok ini menggunakan internet sebagai sarana untuk mendapatkan informasi dan untuk menjaga hubungan yang sudah terbentuk lama melalui komunikasi elektronik. Kelompok ini menggunakan internet antara 4 sampai 5 jam per minggu. Pengguna internet yang adiktif, disebut dependent. Kelompok ini menggunakan aplikasi internet yang berupa komunikasi dua arah untuk bertemu, bersosialisasi dan bertukar ide dengan orang-orang yang baru dikenal melalui internet. Mereka dikelompok ini menggunakan internet antara 20 hingga 80 jam per minggu dengan 15 jam per sesi online. Kelompok ini secara bertahap mengembangkan kebiasaan menggunakan internet. Hal ini dimungkinkan seperti tingkat toleransi yang meningkat pada alkoholik yang secara bertahap meningkatkan konsumsi alkohol untuk memperoleh efek yang diinginkan.

Penelitian-penelitian tentang kecanduan intemet sudah banyak dilakukan. Dari beberapa penelitian yang ada, kebanyakan melihat kecanduan internet pada remaja atau mahasiswa. Seperti yang dilakukan oleh Theodora Natalia Kusumadewi (FPsi UI, 2009) yang melihat hubungan kecanduan internet game online dan keterampilan social pada remaja. ${ }^{15}$ Vida Fallahi dengan judul penelitian Effects of ICT on the youth: A study about the relationship between internet usage and social isolation among Iranian students. ia

\footnotetext{
${ }^{14}$ K.S Young.. Psycology of Computer Use : Addictive Use Of The Internet : A Case Breaks The Stereotype. Psychological Report. 79. 889902. 1996.

${ }^{15}$ lontar.ui.ac.id
} 
menemukan bahwa hasil menunjukkan bahwa\% 13.2 siswa kecanduan internet dan hasil yang lebih menunjukkan perbedaan yang signifikan antara kelompok berbeda pengguna. Kelompok Addicted lebih sendirian daripada kelompok lain. ${ }^{16}$

Penelitian lain dilakukan oleh Nazir S. Hawi yang berjudul Internet addiction among adolescents in Lebanon. Penelitian ini meneliti penggunaan internet di kalangan remaja, yang paling rentan terhadap kecanduan internet. ${ }^{17}$ Soudeh Rahmani, Masoud Gholamali Lavasani dalam penelitian yang berjudul The Relationship Between Internet Dependency with Sensation Seeking and Personality, memprediksi ketergantungan internet dengan mencari sensasi, faktor kepribadian lima besar dan genderdengan sampel dari 179 mahasiswa (109 wanita dan 70 pria) dipilih dari Universitas Teheran menggunakan cluster sampling. ${ }^{18}$

Shu Ching Yang, Chieh-Ju Tung, dengan penelitian Comparison of Internet addicts and non-addicts in Taiwanese high school. Penelitian ini meneliti perbedaan antara pecandu internet dan non - pecandu di sekolah tinggi Taiwan, dan fokus secara khusus pada pola penggunaan internet mereka, dan gratifikasi dan komunikasi kesenangan. ${ }^{19}$

Selim Gunuc, Ayten Dogan, The relationships between Turkish adolescents' Internet addiction, their perceived social support and family activities. Tujuan utama dari penelitian ini

\footnotetext{
${ }^{16}$ Procedia - Social and Behavioral Sciences, Volume 15, 2011, Pages 394-398

${ }^{17}$ Computers in Human Behavior, Volume 28, Issue 3, May 2012, Pages 1044-1053

${ }^{18}$ Procedia - Social and Behavioral Sciences, Volume 30, 2011, Pages 272-277

${ }^{19}$ Computers in Human Behavior, Volume 23, Issue 1, January 2007, Pages 79-96
}

Jurnal Socius Vol. 3, No.1, Th. 2016

ISSN: 2356-4180 adalah untuk mengetahui hubungan antara kecanduan internet remaja, dukungan sosial dirasakan dan kegiatan yang dilakukan dengan ibu, ayah dan keluarga. Ditemukan bahwa sejumlah kegiatan ( menonton T, makan makanan, chatting, belanja dan menghabiskan waktu di luar ) remaja dilakukan dengan ibu mereka meningkat tingkat dukungan sosial yang dirasakan meskipun tingkat kecanduan internet tidak berbeda sehubungan dengan jenis kegiatan yang dilakukan hanya dengan ibu, hanya dengan ayah dan dengan keluarga. ${ }^{20}$

$\mathrm{Lu} \mathrm{Yu,} \mathrm{Daniel} \mathrm{Tan} \mathrm{Lei} \mathrm{Shek,}$ Internet Addiction in Hong Kong Adolescents: A Three-Year Longitudinal Study. Penelitian ini meneliti prevalensi dan berkorelasi psikososial kecanduan internet pada remaja Hong Kong menggunakan desain longitudinal. ${ }^{21}$

Berbeda dengan penelitian dan tulisan yang sudah ada sebelumnya, belum ada penelitian dan tulisan yang melihat ibu sebagai sosok sentral dalam keluarga juga menjadi seorang yang kecanduan internet dalam menjalankan fungsi-fungsi keluarganya. Bagaimana sosok ibu yang kecanduan internet dalam menjalankan fungsi sosialisasi dalam keluarga terutama terhadap anak-anak nya menjadi keunikan utama dalam tulisan ini.

\section{Metode Penelitian}

Artikel ini diawali dengan penelitian yang telah dilakukan dengan jenis studi kasus deskriptif dan termasuk dalam

\footnotetext{
${ }^{20}$ Computers in Human Behavior, Volume 29, Issue 6, November 2013, Pages 2197-2207

21 Journal of Pediatric and Adolescent Gynecology, Volume 26, Issue 3, Supplement, June 2013, Pages S10-S17
} 
penelitian kualitatif. Menurut Yin $^{22}$, studi kasus deskriptif "is the method of choice when the phenomenon under study is not readily distinguisable from it's context". Termasuk dalam penelitian kualitatif karena dirasa mampu menjelaskan keberfungsian keluarga pada keluargakeluarga dengan ibu yang aktif sebagai seorang Kuters, terutama mendeskripsikan bagaimana ibu kuters melaksanakan fungsi sosialisasi dalam keluarga, terutama terhadap anak-anak.

Berdasarkan Mooney (1988) $)^{23}$, studi kasus dalam penelitian ini terkait model analisisnya tergolong studi kasus jamak dengan single level analysis, yaitu studi kasus yang menyoroti perilaku kehidupan dari kelompok individu dengan satu masalah penting. Perilaku kehidupan yang disorot dalam penelitian ini adalah perilaku ibu-ibu pemburu hadia-hadiah kuis-kuis yang diadakan secara online terutama di jejaring sosial facebook. Ibuibu ini online menggunakan internet hampir 12 jam setiap harinya. Perilaku tersebut dikaitkan dengan pelaksanaan fungsi sosialisasi oleh ibu terhadap anakanaknya.

Mengingat ibu-ibu Kuters tersebar hampir di seluruh Indonesia, maka penelitian ini hanya mengambil 5 keluarga ibu-ibu Kuters saja dengan kategori memenangkan kuis lebih dari 25 buah kuis online. Teknik pengambilan informan adalah dengan snowball sampling, yaitu dengan menetapkan seorang informan kunci yaitu Ibu W untuk dapat mengetahui ibu Kuters mana lagi yang layak dijadikan informan. Disamping itu, penelitian juga

\footnotetext{
${ }^{22}$ Yin, R.K. Application of Case Study Research. Applied Social Researh Method Series Volume 34. Sage Pubication, Newburry Park, London and New Delhi, 1993

${ }^{23}$ Salim Agus. Teori dan Paradigma Penelitian Sosial. Tiara Wacana Yogya,2001, hal: 94-95
}

menetapkan informan melalui teknik purpossive sampling, yaitu dengan menetapkan beberapa kriteria, yaitu ibu Kuters yang menang setiap bulan, online 24 jam sehari serta mempunyai anak dan suami.

Jumlah informan dalam penelitian ini adalah 5 ibu kuters, 5 suami ibu kuters, 3 anak ibu kuters dan 3 anggota keluarga lainnya dari ibu kuters. Total jumlah informan dalam penelitian ini adalah 16 orang.

Penelitian ini dilakukan di seluruh Indonesia karena ibu-ibu Kuters tersebar hampir di seluruh Indonesia. Namun, penelitian lebih banyak dilakukan melalui jaringan internet, terutama melalui situs jejaring sosial facebook.

Metode dalam pengumpulan data, yaitu melalui observasi dan wawancara. Observasi yang dilakukan dalam penelitian ini adalah observasi langsung dan tidak langsung. Observasi secara langsung adalah terjun ke lapangan dengan melibatkan seluruh panca indra. Sedangkan observasi secara tidak langsung adalah pengamatan yang dibantu oleh media visual/ audiovisual. ${ }^{24}$

Bentuk observasi langsung yang dilakukan adalah langsung mengamati bagaimana pelaksanaan fungsi sosialisasi oleh ibu kuters, yaitu informan kunci dalam penelitian ini. Untuk pengamatan secara tidak langsung, peneliti juga mengikuti beberapa kuis online sehingga bisa mengamati aktivitas para ibu Kuters di dunia maya, yaitu di jejaring sosial facebook.

Ketika melakukan pengamatan melalui facebook, peneliti harus online dan $\log$ in di jejaring sosial facebook dan

\footnotetext{
${ }^{24}$ Djamaan Satori dan Aan Komariah. 2009. Metodologi Penelitian Kualitatif. Bandung: Alfabeta Bandung, hal: 105
} 
menjalin pertemanan dengan para ibu kuters yang menjadi informan dalam penelitian ini. Karenanya, observasi ini juga tergolong observasi partisipasi. Pengamatan lebih sering difokuskan pada malam hari, karena ibu-ibu kuters lebih sering aktif di malam hari.

Sedangkan wawancara yang dilakukan dalam mendapatkan data-data penelitian ini adalah wawancara mendalam (indepth interview), yaitu proses mendapatkan informasi untuk kepentingan penelitian dengan cara dialog antara peneliti sebagai pewawancara dengan informan dalam konteks observasi partisipasi. ${ }^{25}$

Karena juga memanfaatkan jejaring sosial facebook, wawancara lebih banyak dilakukan melalui media ini, $B B M$, What's App dan juga dengan bantuan email. Untuk membantu memudahkan proses wawancara, peneliti juga mengirimkan email yang berisi angket sederhana dengan pertanyaan-pertanyaan yang bersifat terbuka dan beberapa pertanyaan tertutup. Setelah mendapatkan balasan email, peneliti mewawancara lebih lanjut melalui facebook untuk mendapatkan data yang lebih dalam. Fitur chatt atau inbox melalui facebook menjadi pilihan media yang peneliti gunakan. Khusus untuk Ibu W dan keluarganya, peneliti melakukan wawancara langsung.

Kendala yang dihadapi dalam pengumpulan data melalui teknik ini adalah pendekatan kepada ibu-ibu pemburu kuis ini. Meskipun mengenal 4 orang ibu dari Ibu W, namun mereka tidak langsung mau memberikan jawabanjawaban dari pertanyaan-pertanyaan yang peneliti lancarkan. Akhirnya dengan "pendekatan" yang intensif, barulah para

${ }^{25}$ Ibid, hal: 131

Jurnal Socius Vol. 3, No.1, Th. 2016 ISSN: 2356-4180 ibu ini mau memberikan jawaban yang lebih dalam.

Untuk mendapatkan data yang valid, peneliti menggunakan teknik triangulasi data. Fungsi triangulasi data adalah adalah untuk memahami fenomena sosial dan konstruksi psikologis tidak cukup hanya dengan menggunakan satu alat ukur saja atau triangulasi menekankan digunakannya lebih dari satu metode dan banyak sumber data termasuk di antaranya adalah sejumlah peristiwa yang terjadi.

Triangulasi yang dilakukan dalam penelitian ini adalah triangulasi metode, yaitu membandingkan data hasil wawancara dengan data yang didapatkan melalui observasi. Triangulasi sumber juga digunakan dalam penelitian ini, yaitu dengan membandingkan jawaban dari pertanyaan yang sama dari informan yang berbeda. Data dianggap valid ketika sudah tidak didapatkan lagi variasi data

Analisis dilakukan melalui tiga tahapan yaitu reduksi data, penyajian data dan penarikan kesimpulan. Reduksi data adalah proses pemilihan, pemusatan perhatian pada penyederhanaan, pengabstrakan dan transformasi data yang dikumpulkan di lapangan. Penelitian ini pada awalnya ingin melihat bagaimana pelaksanaan fungsi-fungsi yang ada pada keluarga ibu-ibu kuters. Namun berdasarkan data yang ditemukan, fungsi sosialisasi menjadi fungsi yang dominan, sehingga akhirnya perhatian peneliti lebih tertuju pada pelaksanaan fungsi sosialisasi oleh ibu kuters.

Penyajian data adalah sekumpulan informasi tersusun yang memberi kemungkinan untuk sebagian dari suatu konfigurasi yang utuh, dalam hal ini diwujudkan sebagai jawaban dari pertanyaan penulis. Peneliti berusaha kuat agar penyajian data-data yang ditemukan secara lengkap untuk menjabarkan lebih 
luas apa yang menjadi tujuan dalam penelitian ini.

Wawancara dalam penulisan ini, penulis memberikan interpretasi terhadap data kualitatif yang dicapai melalui interaksi antara penulis dengan narasumber. Analisis data (interpretasi data) adalah suatu proses pelacakan dan pengaturan secara sistematis transkrip wawancara, catatan lapangan dan bahanbahan lain yang dikumpulkan untuk meningkatkan pemahaman terhadap bahan-bahan tersebut agar temuan dapat dipresentasikan.

\section{Aktifitas Ibu-ibu Kuters}

Layaknya ibu-ibu rumah tangga lainnya, ibu-ibu kuters ini juga beraktifitas seperti biasa. Dimulai dengan bangun di pagi hari, menyiapkan sarapan dan juga mengantar anak-anak ke sekolah.

Dari lima orang Ibu-Ibu Kuters yang rata-rata memiliki tiga orang anak usia sekolah, mengaku selalu rutin menyiapkan sarapan dan mengantarkan anak sekolah. Rutinitas lainnya yang dilakukan para ibu ini sembari menunggu anak-anak pulang sekolah dan suami pulang dari kantor, mereka menyiapkan makan siang dan beberes di rumah. Kecuali Ibu W, suaminya yang berkantor di Bandung hanya pulang ke rumah mereka di Bekasi sekali seminggu saja.

Setelah semua pekerjaan ibu rumah tangga mereka jalani, aktifias rutin yang mereka lakukan adalah online di depan komputer PC di rumah. Ibu R, RK dan S mengatakan mereka online di depan komputer rata-rata 4-6 jam sehari. Berbeda dengan Ibu $\mathrm{C}$ dan Ibu W, mereka mengakui online 10-12 jam setiap hari nya.

Para ibu ini menggunakan layanan berlangganan bulanan untuk koneksi internet di rumah mereka dengan biaya Rp. 100.000,- hingga Rp. 300.000,- setiap bulannya. Fasilitas koneksi internet ini juga memungkinkan anggota keluarga lain untuk online melalui wi-fi menggunakan android atau laptop dan tablet.

Untuk keluar rumah, para ibu ini tetap mengaktifkan internet melalui android yang mereka miliki, terutama untuk tetap bisa terhubung dengan jejaring sosial terutama facebook yang selalu menawarkan berbagai kuis online.

Berikut adalah data lama para ibu ini telah menjadi seorang kuis hunters beserta hadiah yang pernah dimenangkan :

\begin{tabular}{|c|c|c|c|c|c|c|}
\hline $\begin{array}{c}\text { Nama } \\
\text { Ibu } \\
\text { Kuters }\end{array}$ & Alamat & $\begin{array}{c}\text { Durasi } \\
\text { online dg } \\
\text { PC/ hari }\end{array}$ & $\begin{array}{c}\text { Lama } \\
\text { Menjadi } \\
\text { Kuters } \\
\text { (Tahun) }\end{array}$ & $\begin{array}{c}\text { Jml Kuis yg } \\
\text { Pernah } \\
\text { Dimenangkan }\end{array}$ & Bentuk Hadiah & $\begin{array}{c}\text { Nilai } \\
\text { Hadiah (Rp) }\end{array}$ \\
\hline W & Bekasi & $10-12$ jam & $1-2$ & $>25$ kuis & $\begin{array}{c}\text { Barang, Voucher Belanja, Voucher } \\
\text { Pulsa Uang, Paket Liburan ke } \\
\text { Singapura bersama 1 anak, umroh } \\
\text { sekeluarga }\end{array}$ & $>25 \mathrm{jt}$ \\
\hline S & Jakarta & $4-6$ jam & $4-5$ & $>25$ kuis & $\begin{array}{c}\text { Barang, Voucher Belanja, Voucher } \\
\text { Pulsa Uang }\end{array}$ & $>25 \mathrm{jt}$ \\
\hline $\mathrm{C}$ & Tangerang & $10-12 \mathrm{jam}$ & $1-2$ & $>25$ kuis & $\begin{array}{c}\text { Barang, Voucher Belanja, Voucher } \\
\text { Pulsa Uang }\end{array}$ & $>25 \mathrm{jt}$ \\
\hline $\mathrm{RK}$ & $\begin{array}{c}\text { Pekan } \\
\text { Baru }\end{array}$ & $4-6$ jam & $1-2$ & $>25$ kuis & $\begin{array}{c}\text { Barang, Voucher Belanja, Voucher } \\
\text { Pulsa Uang }\end{array}$ & $10-15 \mathrm{jt}$ \\
\hline $\mathrm{R}$ & $\begin{array}{c}\text { Yogya- } \\
\text { karta }\end{array}$ & $4-6$ jam & $3-4$ & $>25$ kuis & $\begin{array}{c}\text { Barang, Voucher Belanja, Voucher } \\
\text { Pulsa Uang, Tiket Liburan Gratis } \\
\text { Sekeluarga ke Singapura }\end{array}$ & $>25 \mathrm{jt}$ \\
\hline
\end{tabular}

Jurnal Socius Vol. 3, No.1, Th. 2016 
Bentuk kuis yang biasanya diikuti para kuters ini beragam, misalnya lomba foto dan lomba membuat cerita dengan tema tertentu tergantung pihak yang mengadakan kuis yang tentu saja menyertakan foto atau nama produk penyelenggara kuis. Kalau berhasil memenangkan sebuah kuis me-upload foto beserta hadiah adalah hal yang "wajib" hukumnya bagi para kuters, seperti berikut ini :

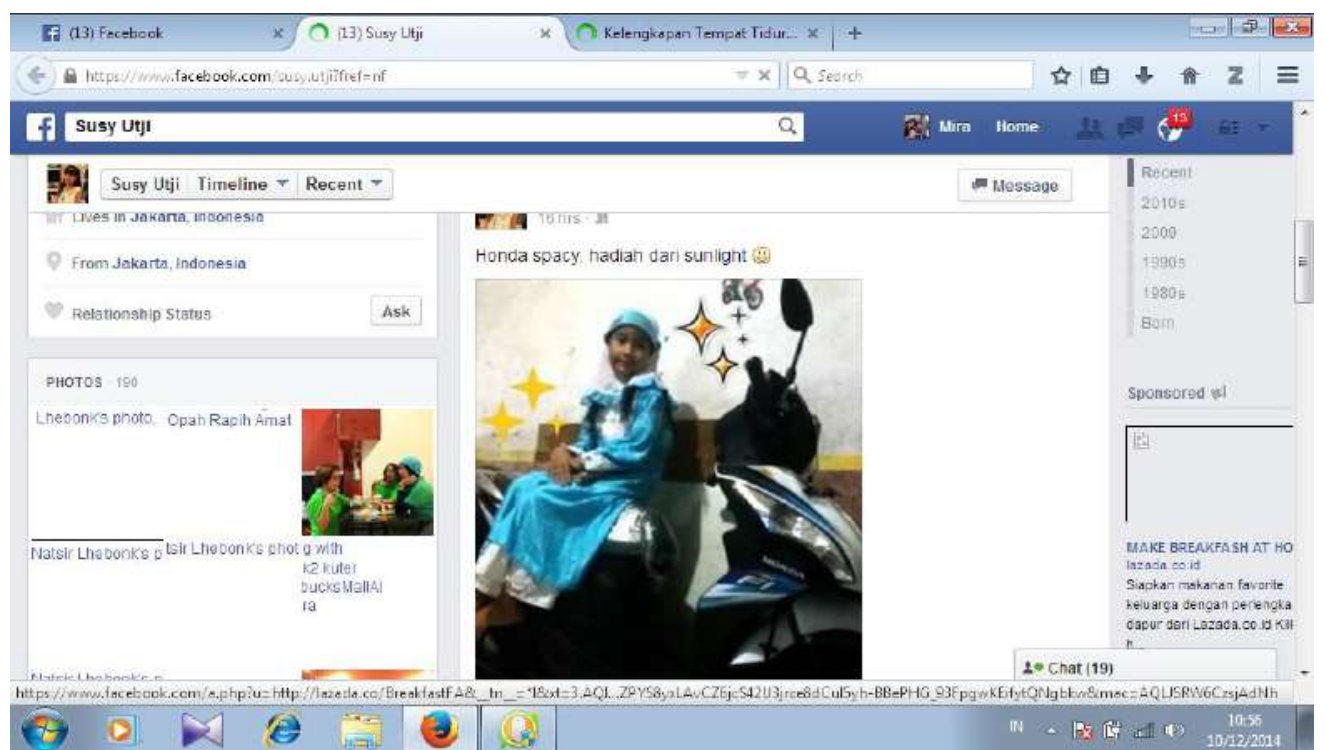

Ket : ketika Ibu S memenangkan hadia motor Honda Spacy dari kuis yang diadakan oleh produk sunlight

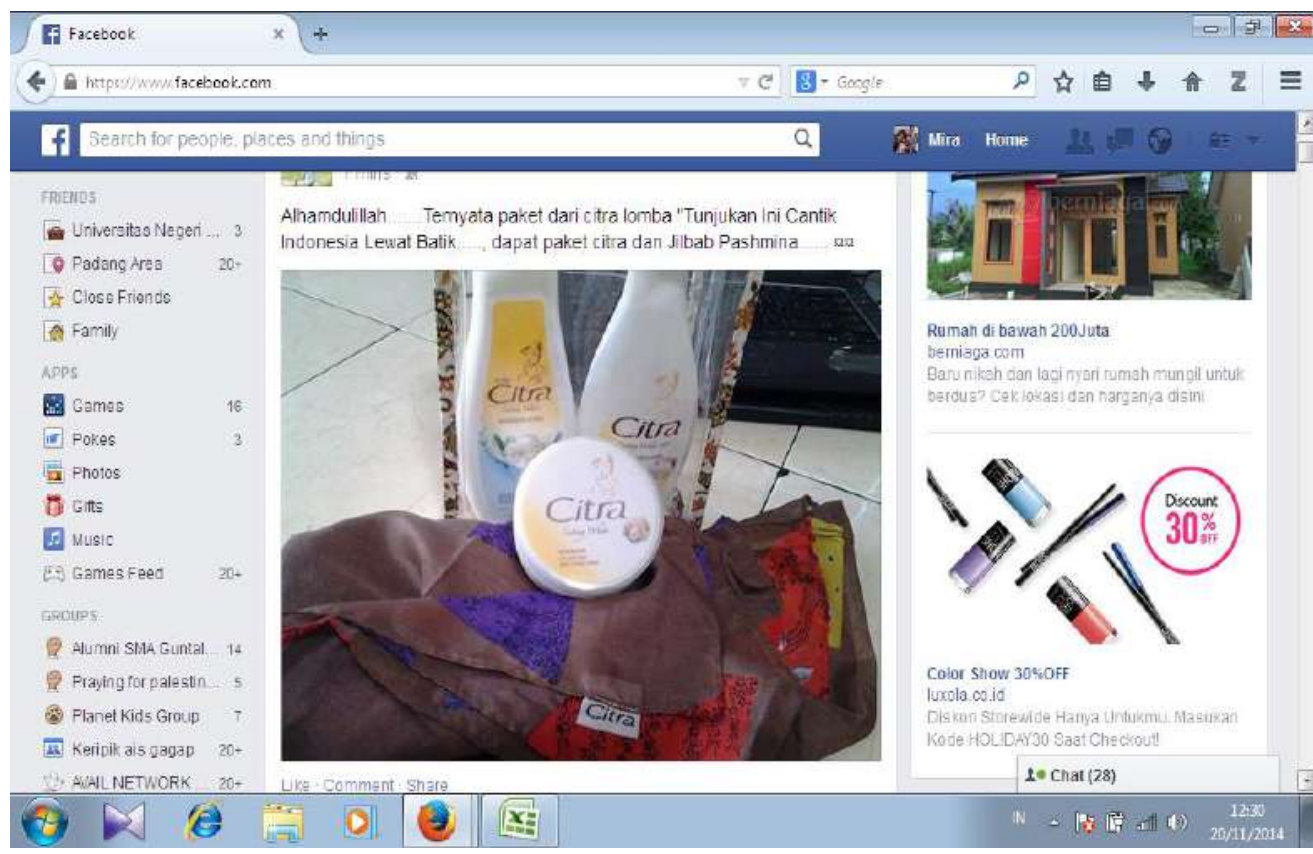

Ket : ketika Ibu W memenangkan hadiah scraft dari kuis yang diadakan produk kecantikan Citra 
Ibu-Ibu Online ...

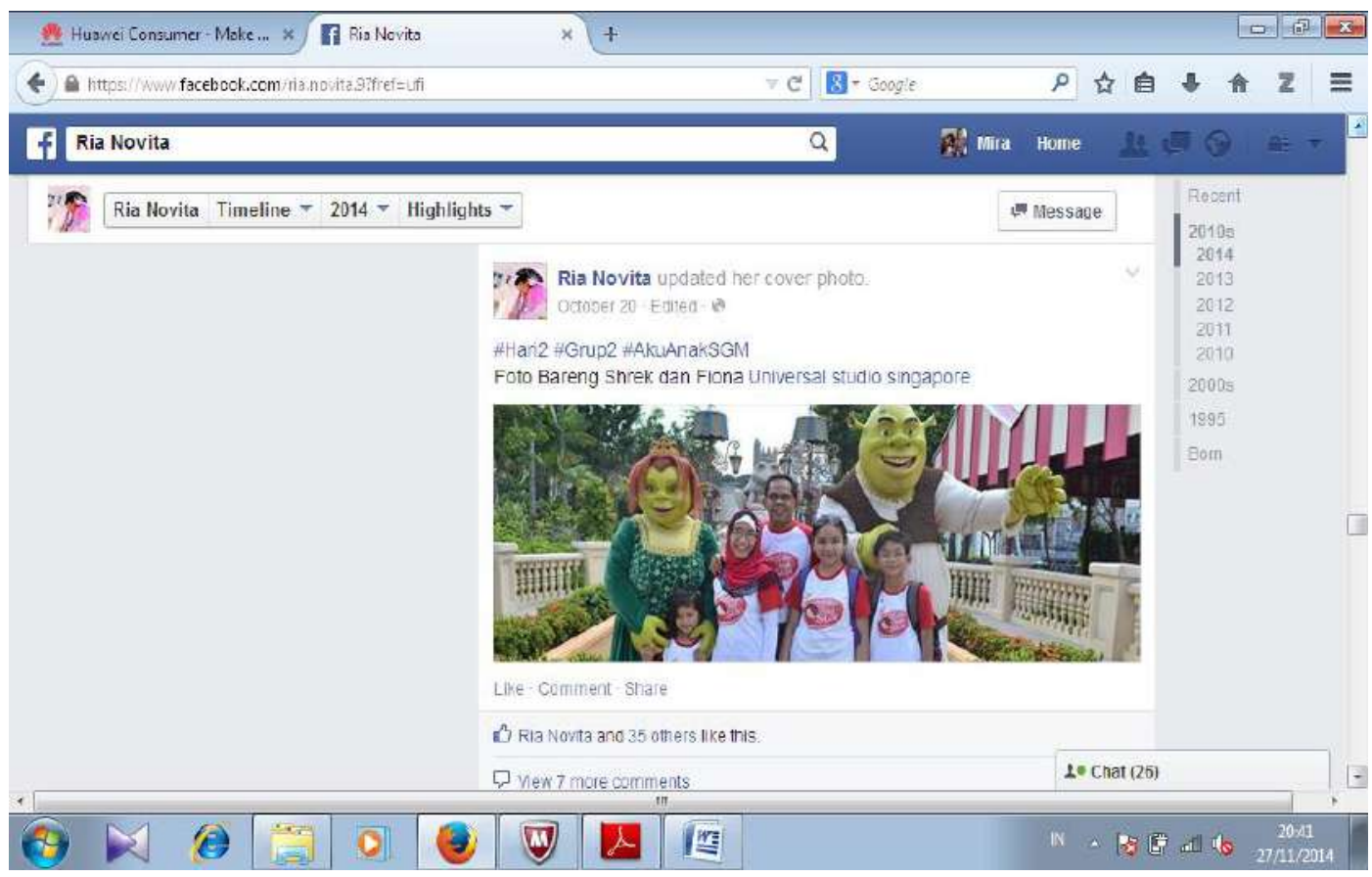

Ket : ketika Ibu R memenangkan paket liburan ke Singapura dari kuis yang diadakan oleh produk susu SGM

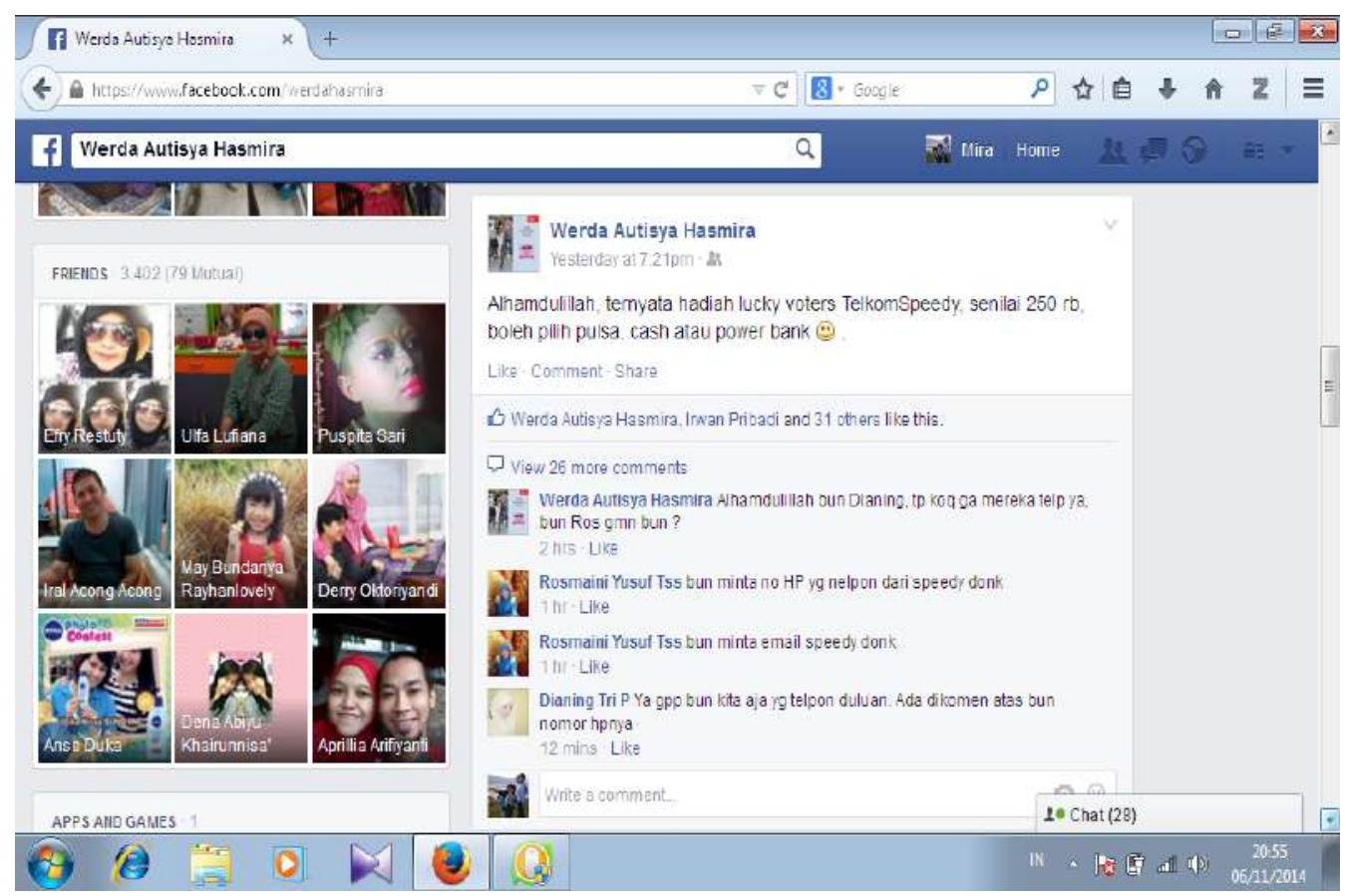

Ket : ketika Ibu W memenangkan hadiah kuis yang diadakan TelkomSpeedy

Jurnal Socius Vol. 3, No.1, Th. 2016 


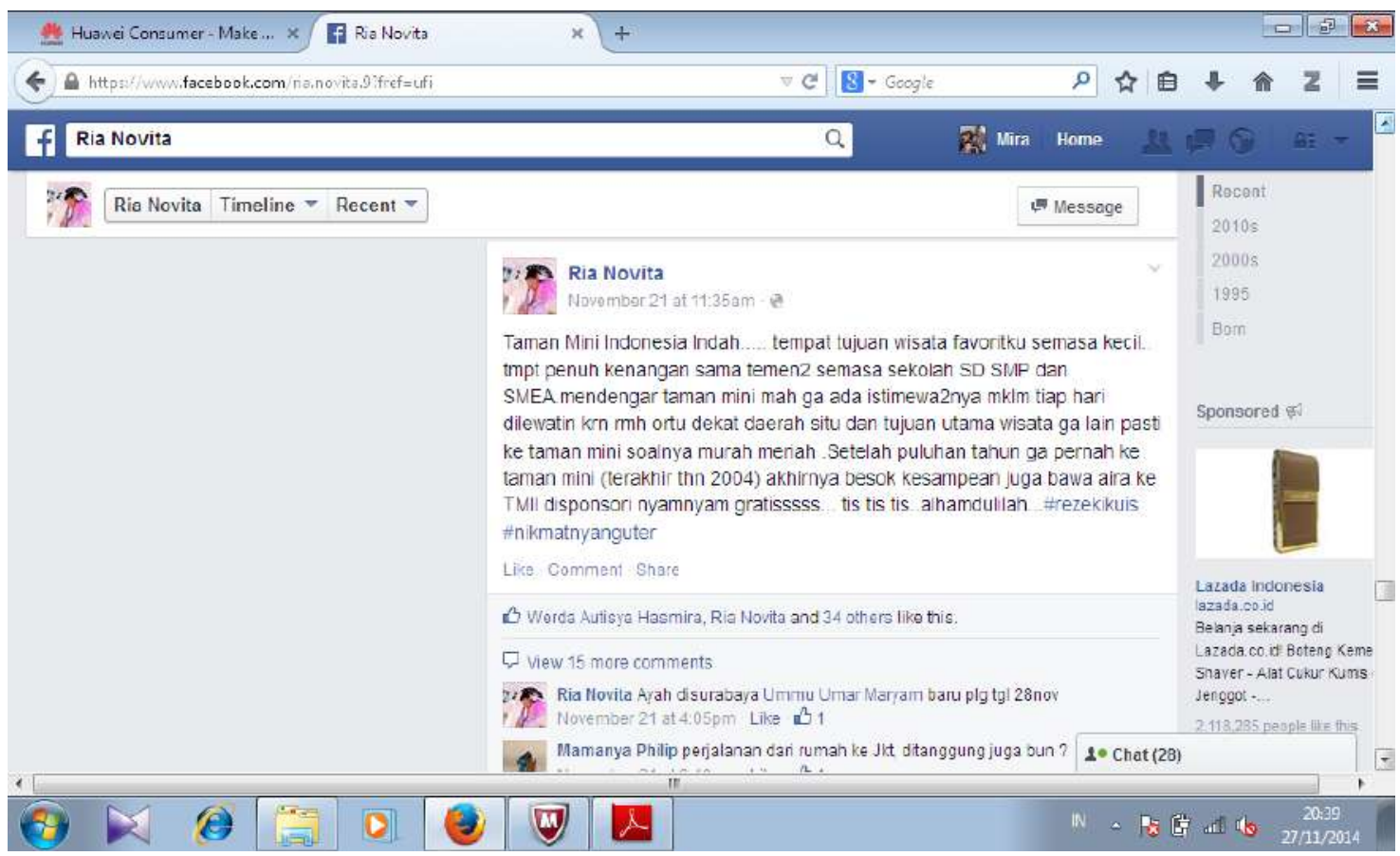

Ket : ketika Ibu R memenangkan paket hadiah jalan-jalan ke TMII

Sebagai pemburu kuis yang aktif dengan aktifitas di dunia maya ini, para ibu ini mengaku selalu didukung oleh suami dan anak-anak, maupun keluarga besar. Seperti yang dilakukan oleh Ibu W, selalu menyampaikan berita bahagia kemenangannya di kuis online kepada seluruh keluarga besarnya. Bahkan tak jarang mengirim hadiah berupa produk yang dimenangkannya ke kakak, adik dan ibunya.

Untuk mengikuti lomba, diperlukan banyak strategi, seperti membuat konsep foto atau cerita yang akan disampaikan dalam sebuah kuis. Para ibu mengatakan bahwa pusingnya membuat konsep sangat terbantu dengan hadirnya ide-ide dari suami.

Karena sudah beberapa kali mengikuti kuis dan sering menang (seperti terlihat pada tabel di atas), ibu-ibu kuters ini tidak mengalami kendala dalam mempersiapkan diri untuk mengikuti kuis- kuis yang ada. Untuk lomba-lomba foto, anak-anak para ibu kuters juga seperti sudah terlatih di depan kamera, terlihat dari foto-foto yang mereka ikutkan di lomba atau hanya sekedar upload di facebook. Berkat lomba foto, anak Ibu C sudah menjadi model sebuah pasta gigi dan si bungsu sudah menjadi bintang iklan di youtube.

Selain saling mengenal di dunia maya, para kuters juga melanjutkan perkenalan di dunia nyata, yang mereka istilahkan dengan kopdar. Terkadang, para ibu kuters juga mengajak suami dan anakanak dalam acara kopdar ini. Para suami akhirnya juga menjadi akrab apalagi anakanak. Pernah ketika salah seorang kuters asal Yogyakarta meninggal karena sebuah kecelakaan, para kuters seluruh Indonesia turut berlangsungkawa dengan mengirimkan bantuan berupa uang kepada keluarga almarhum. 
Kegiatan ini dikelola oleh para kuters yang berdomisili di Yogyakarta. Saling memberi dukungan ketika mengikuti kuis pun terjadi, meskipun para kuters mengikuti kuis yang sama.

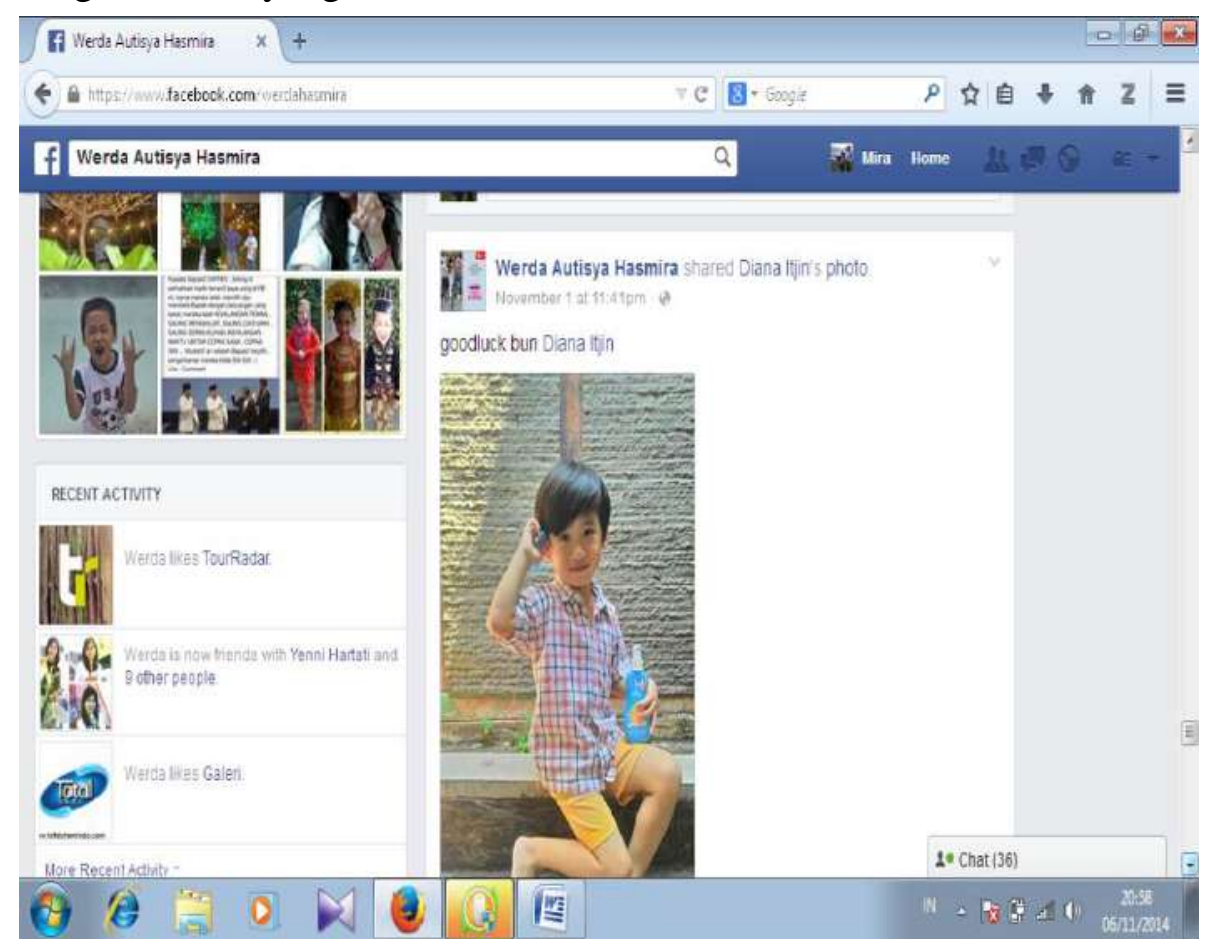

Ket : salah satu bentuk dukungan ke kuters lainnya

Dalam membagi waktu antara berselancar di dunia maya dan menjalankan kewajiban sebagai seorang ibu dan isteri, kadangkala ibu kuters mengalami kendala ketika malamnya harus begadang menunggu pengumuman pemenang atau harus menambah angka like pada lomba foto yang diikuti ketika syarat menjadi salah satu pemenang adalah mereka yang memiliki like paling banyak. Untuk menambah angka like, para kuters tak jarang meminta bantuan keluarga besar, kerabat dan teman-teman di jejaring sosial untuk meng-klik like di foto lomba yang mereka ikutkan. Strategi yang para kuters lakukan untuk ini adalah membuat beberapa akun facebook fiktif, atau membuatkan akun dengan identitas
Bentuk dukungannya memberi like pada foto atau cerita, atau menulis di wallfacebook peserta lain, seperti : 


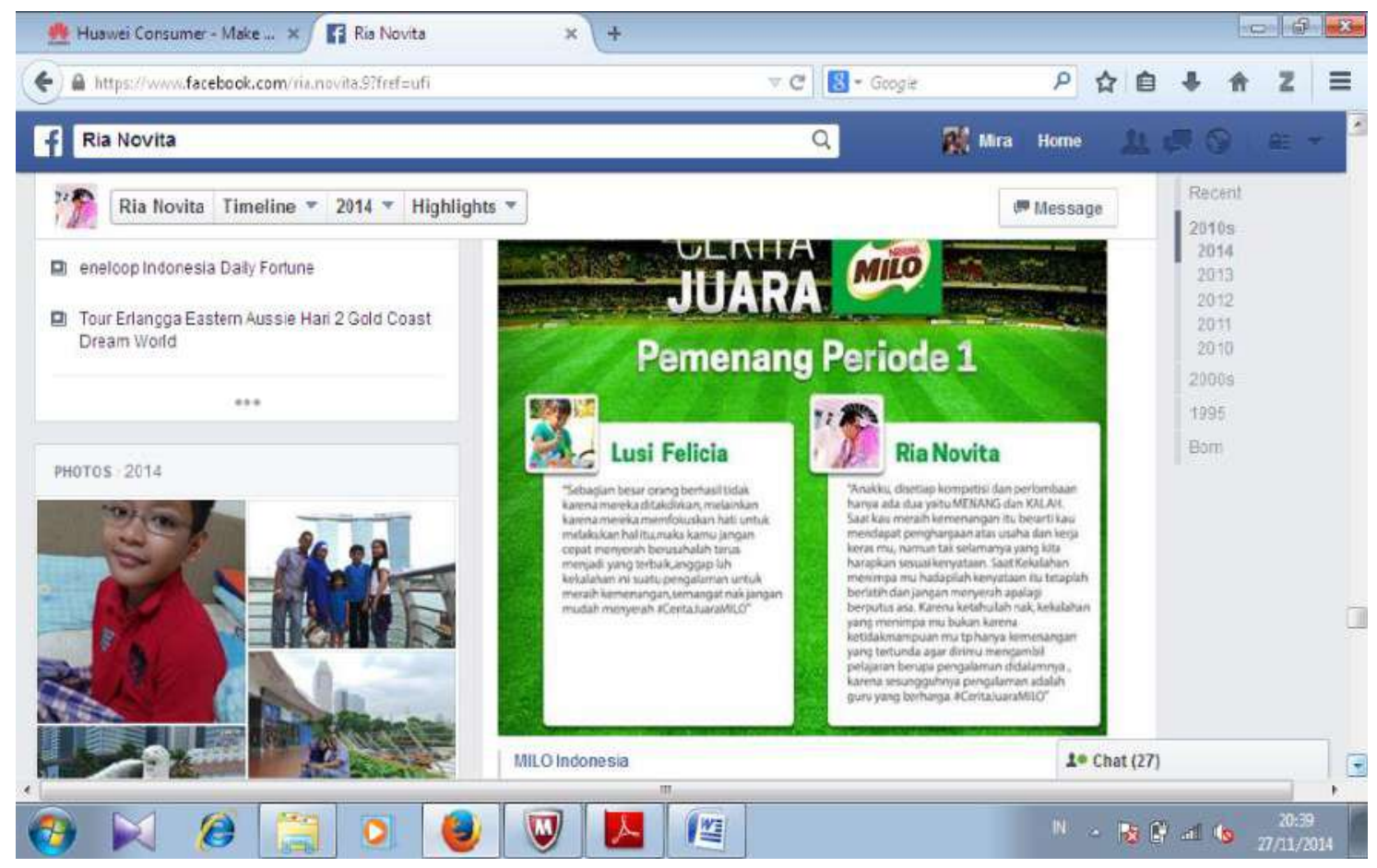

Ket : Ketika Ibu R diumumkan menang oleh admin kuis yang diadakan oleh produk Milo

Pelaksanaan Fungsi Sosialisasi oleh Ibu Kuters

Selayaknya ibu-ibu rumah tangga lainnya, para ibu kuters juga melakukan fungsi penanaman nilai sebagaimana ibuibu rumah tangga lainnya. Anak-anak diajarkan bagaimana bertutur kata yang baik, cara makan yang benar, cara berpakaian yang sopan dan lain sebagainya. Tetapi, berdasarkan observasi yang peneliti lakukan ada hal yang sepertinya tidak disadari langsung oleh para ibu pemburu kuis online ini. Mereka secara tidak langsung telah memberikan contoh bagaimana menjadi seorang pemburu hadiah di dunia maya. Para ibu telah memperlihatkan bagaimana mereka begitu memperdulikan waktu untuk berinternet baik melalui komputer maupun melalui media onlineportable lainnya.

Hal ini terlihat bagaimana anakanak Ibu W sangat familiar menggunakan android mereka untuk mengakses berbagai jejaring sosial. $A B$ yang masih berusia 6 tahun sudah diberikan fasilitas android seharga Rp. 1,6 juta. AB terlihat sudah sangat mahir ketika membuka akun facebooknya hanya untuk sekedar melihatlihat status teman facebooknya atau bahkan memberikan komentar. Mengupload foto-foto hasil jepretannya pun $\mathrm{AB}$ terliha sangat mahir. Dua anak Ibu W lainnya juga diberikan fasilitas android seharga Rp. 1,8 juta masing-masingnya.

Bahkan, anak ibu kuters pun telah menjadi seorang kuters, seperti AP, anak Ibu W yang kedua : 


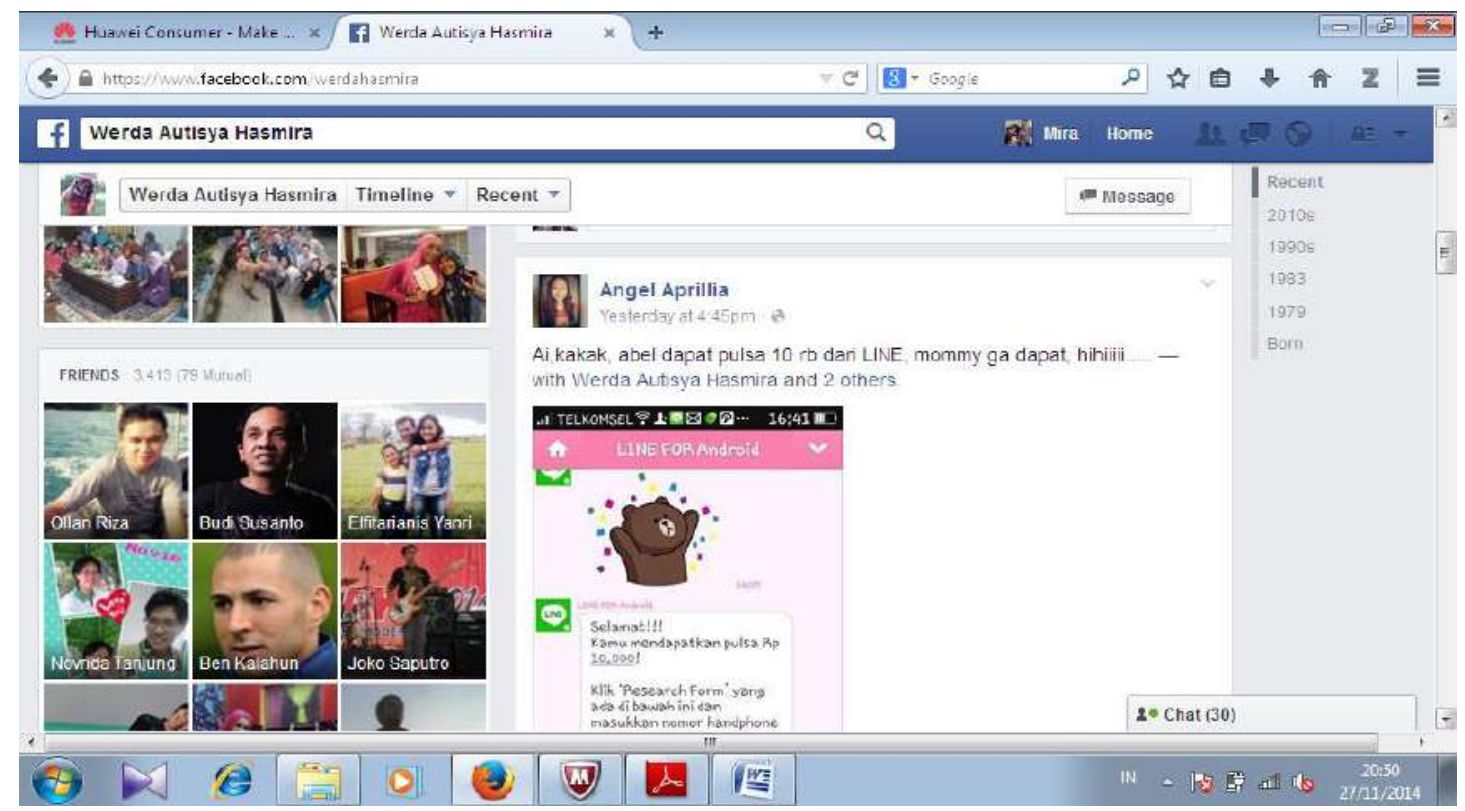

Dari data di atas, dapat diberikan analisa bahwa ibu-ibu kuters menghabiskan hingga 10-12 jam waktunya perhari di depan komputer untuk online setiap harinya. Ditambah selalu terkoneksi dengan internet melalui handphone atau android jika keluar rumah, selalu membuat para ibu kuters ini selalu update dengan info kuis online. Seperti yang ditulis oleh Wallace ${ }^{26}$, bahwa " the internet is no longer something that we 'log into' for particular duration of time, sitting in front of a desktop computer"

Maksudnya bahwa internet tidak lagi sesuatu yang harus dilakukan dengan jangka waktu tertentu dengan duduk di depan komputer. Kebiasaan para ibu ini bisa dikategorikan sebagai sebuah kecanduan internet, meskipun mereka tidak menyadari bahwa mereka tergolong pecandu internet. Seperti yang dijabarkan oleh Young bahwa seorang pecandu

\footnotetext{
${ }^{26}$ Patrisia Wallace,2014. Internet Addiction Disorder and Youth dalam EMBO reports vol 15/ no $1 / 2014$
}

Jurnal Socius Vol. 3, No.1, Th. 2016

ISSN: 2356-4180 internet tidak merasa dirinya kecanduan internet bahkan tidak mau disebut pecandu internet karena perilaku online nya berlebihan.

Namun, ibu-ibu kuters ini dapat dikategorikan sebagai pengguna internet secara sehat seperti yang dikatakan oleh Suler. Hal ini karena, pertama, ibu-ibu kuters ini mampu memadukan dunia nyata nya sebagai ibu dan isteri dengan tetap menjalankan rutinitas sebagai ibu rumah tangga lainnya dengan cyberspace dimana mereka berpetualang menjadi seorang pemburu hadiah dalam kuis-kuis online. Kedua, kenapa ibu-ibu kuters ini dikategorikan sebagai pengguna internet yang menggunakan internet secara sehat adalah karena mereka membicarakan aktifitas online mereka dengan keluarga, teman-teman baik melalui telpon maupun bertemu secara langsung, seperti yang dilakukan oleh Ibu W dengan keluarganya. Ketiga, kenapa peneliti mengelompokkan ibu-ibu kuters ini kedalam kelompok pengguna internet secara sehat adalah karena merekapun 
bertemu secara real dengan teman-teman yang mereka kenal secara online dalam kegiatan yang mereka namai kopdar.

Namun, hal yang tidak disadari telah dilakukan oleh para ibu-ibu kuters adalah ketika menjalankan fungsi sosialisasi kepada anak-anaknya. Secara tak langsung, ibu telah memberikan contoh kepada anaknya tentang bagaimana ibu menjadi seorang yang kecanduan internet.

Keluarga sebagai sumber utama dan pertama dalam proses penanaman nilai atau sosialisasi, secara nyata telah melakukan internalisasi terhadap anak bagaimana menjadi seorang pemburu hadiah di kuis-kuis online. Hal ini terlihat pada beberapa proses yang sangat mempengaruhi hasil interaksi antara anakanak dengan ibu pecandu internet, yaitu: pertama dari proses peniruan (imitasi) perilaku online yang diperlihatkan ibu membuat anak-anak sangat familiar dengan online terutama mengakses jejaring sosial. Kedua, sugesti yang diberikan ibu bahwa ketika ibu memperlihatkan kebahagiaannya ketika memenangkan kuis, memberikan motivasi kepada anak-anak untuk ikut berpartisipasi mengikuti kuis online. Seperti yang terjadi pada anak-anak Ibu $\mathrm{W}$, antusias ketika melihat iklan di TV bahwa sebuah produk mengadakan kuis online.

Ketiga, dalam proses identifikasi, disaat anak cenderung ingin menjadi sama dengan ibunya menjadi pemenang dalam berbagai kuis online. Sehingga, anak pun mulai belajar bagaimana caranya menjadi kuters seperti yang terjadi pada AP, anak Ibu W yang masih kelas 4 SD. Keempat, adalah simpati yang diwujudkan melalui sebuah kerjasama. Para ibu kuters memberdayakan anak-anak mereka bahkan suami mereka untuk menjadi model foto atau tokoh di dalam narasi pendek mereka dalam sebuah kuis online.

Jadi, jika digambarkan dalam sebuah bagan, berikut adalah bagaimana nilai "pecandu internet sehat" yang disosialisasikan oleh ibu kuters kepada anak-anaknya sehingga anak anak juga menjadi pecandu internet dan berjam-jam online diangggap sebagai sesuatu yang biasa:

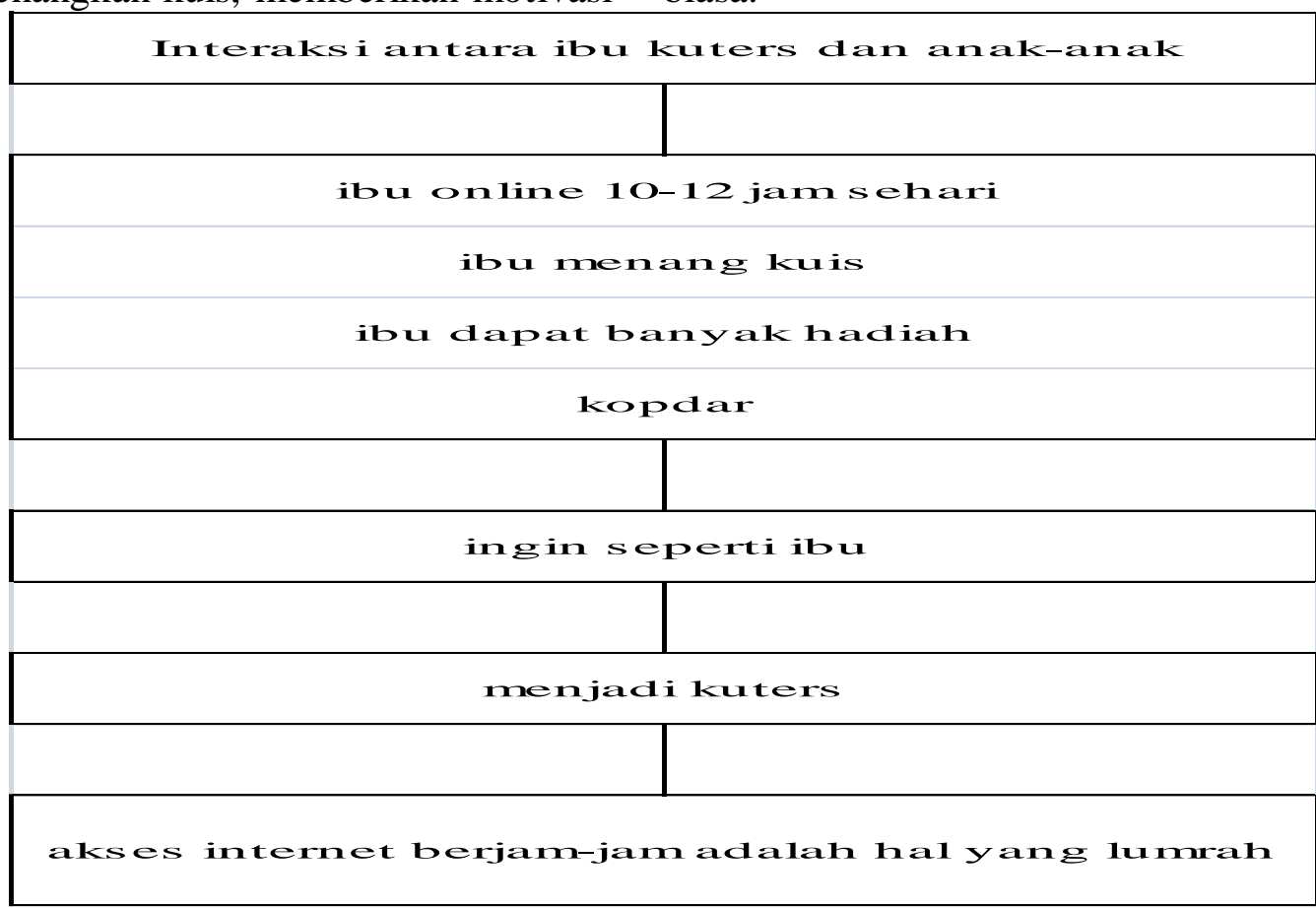

Jurnal Socius Vol. 3, No.1, Th. 2016 


\section{Penutup}

Para ibu kuters ini dapat dikategorikan sebagai pengguna internet secara sehat seperti yang dikatakan oleh Suler. Hal ini karena, pertama, ibu-ibu kuters ini mampu memadukan dunia nyata nya sebagai ibu dan isteri dengan tetap menjalankan rutinitas sebagai ibu rumah tangga lainnya dengan cyberspace dimana mereka berpetualang menjadi seorang pemburu hadiah dalam kuis-kuis online. Kedua, kenapa ibu-ibu kuters ini dikategorikan sebagai pengguna internet yang menggunakan internet secara sehat adalah karena mereka membicarakan aktifitas online mereka dengan keluarga, teman-teman baik melalui telpon maupun bertemu secara langsung, seperti yang dilakukan oleh Ibu W dengan keluarganya. Ketiga, kenapa peneliti mengelompokkan ibu-ibu kuters ini kedalam kelompok pengguna internet secara sehat adalah karena merekapun bertemu secara real dengan teman-teman yang mereka kenal secara online dalam kegiatan yang mereka namai kopdar.

Secara tidak disadari telah dilakukan oleh para ibu-ibu kuters adalah ketika menjalankan fungsi sosialisasi kepada anak-anaknya. Secara tak langsung, ibu telah melakukan sosialisasi kepada anakanaknya bagaimana menjadi seorang pemburu hadiah di kuis-kuis online.

Beberapa proses yang sangat mempengaruhi hasil interaksi antara anakanak dengan ibu pecandu internet, yaitu: pertama dari proses peniruan (imitasi) perilaku online yang diperlihatkan ibu membuat anak-anak sangat familiar dengan online terutama mengakses jejaring sosial. Kedua, sugesti yang diberikan ibu bahwa ketika ibu memperlihatkan kebahagiaannya ketika memenangkan kuis, memberikan motivasi kepada anak-anak untuk ikut

Jurnae Socius Vol. 3, No.1, Th. 2016 berpartisipasi mengikuti kuis online. Ketiga, dalam proses identifikasi, disaat anak cenderung ingin menjadi sama dengan ibunya menjadi pemenang dalam berbagai kuis online. Keempat, adalah simpati yang diwujudkan melalui sebuah kerjasama. Para ibu kuters memberdayakan anak-anak mereka bahkan suami mereka untuk menjadi model foto atau tokoh di dalam narasi pendek mereka dalam sebuah kuis online. Dapat disimpulkan lebih ringkas bahwa Ibu mensosialisasikan nilai "pecandu internet sehat" kepada anak-anaknya sehingga anak anak juga menjadi pecandu internet dan berjam-jam online diangggap sebagai sesuatu yang biasa.

\section{Daftar Pustaka}

Lestari, Sri. 2012. Psikologi Keluarga. Jakarta : Kencana Prenada Media Grup

Nistanto, Reska K. 2014.Facebook Ungkap Jumlah Penggunanya di Indonesia|. Kompas.com: Senin,.22 September,

Salim, Agus. 2001. Teori dan Paradigma Penelitian Sosial. Yogya : Tiara Wacana

Satori, Djamaan dan Aan Komariah. 2009. Metodologi Penelitian Kualitatif, Bandung : Alfabeta

Severin, J Warner. 2011. Teori Komunikasi : Sejarah, Metode dan Terapan di Dalam Media Massa. Jakarta : Kencana Prenada Media Grup 
Suhendi, Hendi dan Ramdani Wahyu. 2001. Pengantar Studi Sosiologi Keluarga. Bandung : Pustaka Setia

Suler, J. 1996. Computer and Cyberspace Addiction (online). Rider Univer sity http://www1.Rider.edu /suler /psycyber/psycyber.html

Wahyudi, Reza. Facebook Buka Kantor di Indonesia. Kompas.com: 21 Maret 2014.

Yin, R.K. 1993. Application of Case Study Research. Applied Social Researh Method Series Volume 34. Newburry Park, London and New Delhi : Sage Pubication

Young, K.S.1996. August 15, Internet Addiction : The Emergence of $A$ New Clinical Disorder. Canada: Paper presented at the 104th annual meeting of the American Psychology Association

Young, K.S. 1996. Psycology of Computer Use : Addictive Use Of
The Internet : A Case Breaks The Stereotype. Psychological Report. 79. 889-902.

Jurnal online :

Computers in Human Behavior, Volume 23, Issue 1, January 2007, Pages 79-96

Computers in Human Behavior, Volume 28, Issue 3, May 2012, Pages 1044-1053

Computers in Human Behavior, Volume 29, Issue 6, November 2013, Pages 2197-2207

Procedia - Social and Behavioral Sciences, Volume 15, 2011, Pages 394-398

Procedia - Social and Behavioral Sciences, Volume 30, 2011, Pages 272-277

Journal of Pediatric and Adolescent Gynecology, Volume 26, Issue 3, Supplement, June 2013, Pages S10-S17 